\title{
Metabolic Syndrome: Differences for Asian Americans is in Their Body Fat Percentages
}

Asian/Pacific Island Nursing Journal Volume 1(3): 70-81

(CAuthor(s) 2016

http://digitalscholarship.unlv.edu/apin/

\author{
Patricia T. Alpert ${ }^{\mathrm{a}}$ and Diane Thomason ${ }^{\mathrm{b}}$
}

\begin{abstract}
Asian Americans are not frequently thought of as being obese or overweight yet some of the Asian American subgroups have a disproportionate risk for cardiovascular disease and type 2 diabetes mellitus. Although the standardized body mass index (BMI) assessment is an adequate tool for reporting secular prevalence trends for overweight/obesity across populations, it falls short in accuracy when assessing Asian Americans. In recent years more has been written about the re-evaluation of BMI cut points for normal weight, overweight, or obese Asian Americans. Additionally, the waist circumference norm was modified to indicate a smaller waist size is a risk for metabolic syndrome. The purpose of this paper is to provide an overview of the research literature on BMI and percentage of body fat as it relates to health risk for metabolic syndrome for Asian American subgroups.

Three databases were used to identify articles for this review: Google Scholar, CINHAL, and PubMed. Seven hundred twenty-six articles were initially identified as meeting the criteria; 690 articles were eliminated after a review of the article titles revealed the content did not meet the focus of this review. Of the remaining articles, 19 were eliminated after a review of the abstracts indicated they were meta-analyses, review articles, or case studies. The remaining 18 articles were included in this review.

Three common themes emerged. (1) The differences in BMI and body fat percentage are evident between Asian Americans and other ethnic groups. (2) Differences in the percentage of body fat exist between Asian American subgroups, and between Asian Americans and Asian immigrants. (3) There are differences in disease development end points when comparing Asian American subgroups and Asian immigrant subgroups.

There are differences in body fat distribution and body fat percentages as well as BMI compared to other ethnic groups for metabolic syndrome. There are also differences between Asian immigrant/Asian American subgroups whereby some are more susceptible to diabetes and cardiovascular disease. Research is necessary to determine if these differences have an underlying genetic predisposition. Additionally, researchers need to oversample Asian immigrant/Asian American participants in comparison studies and need to identify each subgroup in their research rather than aggregating Asian immigrants/Asian Americans by geographical origin or as one common group designated as a generic group of "Asians."
\end{abstract}

Keywords: Asian Americans, obesity, anthropometric measurements, BMI, body fat distribution

While the obesity epidemic is discussed in most major professional health journals, there is much more to learn about this major public health issue especially as it relates to the various ethnic/racial groups. Obesity can be considered the core factor in the constellation of metabolic risk factors known as metabolic syndrome (previously referred to as Syndrome X; Després, 2012; Fujimoto et al., 1999). As the epidemic of metabolic syndrome increases in the Asian American population, questions arise because Asian Ameri- cans are less likely to be classified as overweight or obese (Ogden, Carroll, Kit, \& Flegal, 2013).

Metabolic syndrome is more common in Asian Americans than in non-Hispanic Whites ${ }^{a}$ Arizona College, Las Vegas Campus, USA

${ }^{b}$ University of Nevada, Las Vegas, USA

Corresponding Author:

Patricia T. Alpert, DrPH, MSN, FNP-BC, PNP-BC, CNE, FAANP, Founding Dean, School of Nursing, Arizona College, Las Vegas Campus, Las Vegas, NV 89102, USA

Email: palpert@arizonacollege.edu 
(Palaniappan, Wong, Shin, Fortmann, \& Lauderdale, 2011). The reason for concern is because the Asian American population is one of the nation's fasting growing ethnic/racial groups, growing at a rate four times that of the total U.S. population (Colby \& Ortman, 2014). In 2011, over 18.2 million individuals living in the United States self-identified as Asian American, with nearly two-thirds claiming to be foreignborn (Colby \& Ortman, 2014). Equally important is the difference in anthropometric measurements and physiological factors associated with metabolic syndrome in this population compared to other ethnic/racial groups. These differences may indicate a greater risk for diabetes and cardiovascular disease (CVD) due to late identification and treatment for metabolic syndrome. It is imperative to identify the potential differences in anthropometric measurements because they warrant different approaches to treatment of not only the physiological parameters but also the cultural beliefs, dietary habits, and behavioral patterns.

This overview describes the characteristics of the anthropometric measurements, such as body mass index (BMI) and body fat percentage associated with metabolic syndrome among Asian Americans compared with other ethnic/racial groups in the general population (Bates, Acevedo-Garcia, Alegría, \& Krieger, 2008; Yates, Edman, \& Aruguete, 2004). Results indicated that the standard BMI guidelines for overweight and obesity cannot be applied to the Asian American population without modifying the standard parameters downward. Some of the research metrics for obesity using BMI and waist-to-hip ratio (body fat percentages) for Asian Americans have mixed results. One explanation is that studies have used different subgroups of Asian Americans or used Asian Americans as single aggregated study groups, making it difficult to translate findings across all subgroups.

\section{Background Information}

According to the National Cholesterol Education Program Expert Panel on Detection, Evaluation, and Treatment of High Blood Cholesterol in Adults (2002), individuals with three or more of the following risk factors are diagnosed with Metabolic Syndrome: (a) an elevated blood pressure equal to or greater than 130/85 $\mathrm{mmHg}$, (b) a reduction of highdensity lipoprotein (males: < $40 \mathrm{mg} / \mathrm{dL}$ and women: < $50 \mathrm{mg} / \mathrm{dL}$ ), (c) a fasting blood sugar level of $\geq 100$ $\mathrm{mg} / \mathrm{dL}$, (d) a waist circumference of $\geq 40$ inches for males or $\geq 35$ inches in women, and (e) an elevated triglyceride level of $\geq 150 \mathrm{mg} / \mathrm{dL}$. Those with metabolic syndrome are two times more likely to develop CVD, five times more likely to develop type 2 diabetes mellitus (T2 DM), and more likely to develop sleep apnea, fatty liver disease, and orthopedic problems (Després et al., 2000; Ford, Giles, \& Dietz, 2002).
Logically, if these risk factors are curtailed, long-term adverse effects can be prevented or minimized. Additionally, population-based and longitudinal studies indicated those with elevated BMI $\left(>30 \mathrm{~kg} / \mathrm{m}^{2}\right.$, defined as obese [Center for Disease Control \& Prevention (CDC), 2015]) or larger waist circumferences (males: $\geq 40$ "; females: $\geq 35$ "; CDC, 2015) are the most at risk for this syndrome, and ultimately at greater risk for the development of CVD and T2 DM.

The single most important factor in controlling metabolic syndrome is to prevent or reverse obesity (Han et al., 2002; Palaniappan et al., 2004). According to the CDC (2015), those with a BMI of $>25$ $\mathrm{kg} / \mathrm{m}^{2}$ are considered to be overweight and those with a BMI of $>30 \mathrm{~kg} / \mathrm{m}^{2}$ are categorized as obese. Evidence indicates there are differences in BMI measurements for the various ethnic/racial groups with different cut point values indicating risk for disease.

Using the standard definition of obesity (BMI cut points), the CDC oversampled Asian Americans in the 2011-2012 National Health and Nutrition Education Survey. Their findings indicated the prevalence of obesity in the Asian American population was 10.8\% compared to $34.9 \%$ for all U.S. adults (Ogden, Carroll, Kit, \& Flegal, 2014). This finding is in contrast to several Asian American studies, which indicated an increased risk for diabetes in spite of lower BMI categorizations (Hsu et al., 2015; McNeely \& Boyko, 2004; Oza-Frank, Ali, Vaccarino, \& Narayan, 2009).

Metabolic syndrome in Asian Americans is poorly understood due to the lack of data supporting its prevalence. In general, data for CVD and T2 DM in Asian Americans indicated an increased number affected at lower BMI values than the standard BMI definition for overweight and obesity. Studies conducted in Asian countries such as China (Ko, Chan, Cockram, \& Woo, 1999), Korea (Jee et al., 2006), Singapore (Deurenberg-Yap et al., 2001), and the Philippines and Taiwan (Gallagher et al., 2000; Palaniappan et al., 2011) also demonstrated a higher risk for CVD and T2 DM. These findings led the World Health Organization (WHO) to revise the BMI definition of overweight and obesity for Asians. The revised BMI range of $23.0-27.4 \mathrm{~kg} / \mathrm{m}^{2}$ is now considered overweight for Asians with a BMI of $\geq 27.5 \mathrm{~kg} / \mathrm{m}^{2}$ defined as obese (WHO, 2004; Table 1).

Table 1. BMI Cutoff Points for Asians vs. for Other Ethnic Groups

\begin{tabular}{lll}
\hline $\begin{array}{l}\text { BMI } \\
\text { Values }\end{array}$ & Asians & $\begin{array}{l}\text { All Other } \\
\text { Ethnic Groups }\end{array}$ \\
\hline Underweight & $<18.5 \mathrm{~kg} / \mathrm{m}^{2}$ & $<18.5 \mathrm{~kg} / \mathrm{m}^{2}$ \\
Normal & $18.5-22.9 \mathrm{~kg} / \mathrm{m}^{2}$ & $18.5-24.9 \mathrm{~kg} / \mathrm{m}^{2}$ \\
Overweight & $23.0-27.4 \mathrm{~kg} / \mathrm{m}^{2}$ & $25.0-29.9 \mathrm{~kg} / \mathrm{m}^{2}$ \\
Obese & $\geq 27.5 \mathrm{~kg} / \mathrm{m}^{2}$ & $\geq 30.0 \mathrm{~kg} / \mathrm{m}^{2}$ \\
\hline
\end{tabular}

Note. Source: WHO, 2004 


\section{Method}

This literature review focused on Asian American obesity using BMI and body fat percentages. Google Scholar, CINAHL, and PubMed were used to identify articles that met the review criteria. Key words included (a) Asian immigrants/Asian Americans and obesity, (b) Asian immigrants/Asian Americans and BMI, (c) Asian immigrants/Asian Americans and waist circumference, and (d) Asian immigrants/Asian Americans and body fat distribution. Inclusion criteria were articles related to (a) Asian adults either born in the United States or migrated to the United States; (b) Asian Americans classified as overweight or obese according to BMI or body fat percentages; (c) anthropometric measurements, such as BMI or percentage of body fat, associated with metabolic syndrome or T2 DM in Asian Americans; (d) studies in peer-reviewed journals written in English; and (e) studies published within the past two decades (1995-2015). Exclusion criteria included (a) Asian Americans/Asian immigrants younger than 18 years of age; (b) dissertations, theses, unpublished papers, and book chapters; (c) intervention studies; and (d) articles on body fat assessment in individuals with diagnosed diseases. A total of 726 articles were identified; 690 articles were eliminated based on titles not reflecting the focus of this review. Of the remaining articles, 19 did not meet inclusion criteria after reviewing the abstracts and were eliminated. After eliminating review articles, meta-analyses, and case studies, 18 articles were included in this review. Both researchers reviewed and eliminated the articles that did not meet the inclusion criteria. The authors met to discuss articles they differed on until consensus was reached.

\section{Results: Common Themes}

Research data have indicated the relationship between BMI and body fat composition differs between the different ethnic/racial groups. Obesity as defined by BMI is a well-known risk factor for metabolic syndrome, but BMI parameters are being questioned in Asian Americans. Historically, Asian Americans are overlooked or understudied when assessing obesity rates because of the belief their rates are lower than other ethnic groups. The studies reviewed here were peer-reviewed journal articles involving Asian Americans or immigrant Asians living in the United States with anthropometric measurements associated with risk for diabetes and CVD. There were several studies included in this review of disaggregated Asian data analyses which have shown heterogeneity in health profiles. The results from these studies should be interpreted with caution. This review identified common themes discussed below. A total of 2,870,326 study participants were included in this review.

\section{Differences in Body Fat and BMI}

The comparison studies of overweight or obese U.S. born Asians compared to their foreign-born counterparts (Palaniappan et al., 2011) demonstrated those living in the United States (based on length of residency in the United States) correlated with increased weight or elevated BMI (Jih et al., 2014; Lauderdale \& Rathouz, 2000; Park, Neckerman, Quinn, Weiss, \& Rundle, 2008; Sánchez-Vaznaugh, Kawachi, Subramanian, \& Acevedo-Garcia, 2008). Because most of these studies are simple comparisons, prevalence or descriptive analyses, the true nature of obesity and its related disease associations document contradictory data for this ethnic group. Additionally, studies assessing the association between acculturation (taking on the Western lifestyle, including eating Western foods) and BMI among Asians who migrated to Western countries are inconsistent. For example, some found no association (Kaushal, 2009; Park et al., 2008) while others found an association (Gomez, Kelsey, Glaser, Lee, \& Sidney, 2004; Oakkar et al., 2015; Oza-Frank \& Narayan, 2010).

\section{Paradox of BMI Values and Percentage of Body Fat}

From a physiological perspective, obesity is not the degree of body weight but the percentage of accumulated body fat that is related to disease risk factors. The realization that some ethnic groups have higher percentages of body fat content compared to their stated BMIs came to light with the discovery that Asians have lower BMIs but higher body fat percentages compared to Caucasians of the same age and sex. Seemingly, the tendency for central or abdominal obesity might be greater for Asian Americans when compared with non-Asians. It is this left shift in BMI with higher body fat percentages that led to the reassessment of BMI cut points for Asian Americans.

Gallagher et al. (2000) found differences in the paradox of lower BMI and higher percentage of body fat in Japanese living in the United States and the United Kingdom compared to Caucasians and African Americans. According to Araneta and Barrett-Connor (2005), Filipino women living in California with normal adjusted BMIs of $<23 \mathrm{~kg} / \mathrm{m}^{2}$ had more intra-abdominal visceral fat compared to Caucasian and African-American women with normal BMIs of $<25$ $\mathrm{kg} / \mathrm{m}^{2}$.

\section{Differences Between Asians}

Weight studies assessing subgroups of Asian Americans yielded different findings across Asian American populations suggesting all Asian Americans should not be grouped together as one ethnic/racial 
category. All Asian American subgroups are not similar when comparing BMI and fat percentages. According to Oakkar et al. (2015), a substantial heterogeneity is reflected in the longitudinal data that assessed acculturation and BMI. Among the foreign-born Asians in their California Men's Health Study, they found that Filipinos and Koreans had higher rates of weight gain compared to Chinese. They postulated their findings to mean BMI curves differ by Asian American subgroups.

Several studies over the past two decades that have compared body fat percentages among various Asian American subgroups have indicated not all Asian Americans are equal in body fat composition (Albrecht et al., 2013; Gomez et al., 2004; Lauderdale \& Rathouz, 2000; Oza-Frank et al., 2009). These findings in Asian Americans are supported by research conducted in other Asian countries. For example, Deurenberg-Yap et al. (2001) found distinct differences in BMI/percentage body fat composition (as measured by waist-to-hip ratios) with Chinese, Indonesians, and Thais at greater risk for co-morbidities for CVD with lower BMIs and waist-to-hip ratios. Another comparison of Chinese living in Beijing, Hong Kong, and New York also showed differences in BMI/body fat percentages (Deurenberg-Yap, Schmidt, van Staveren, \& Deurenberg, 2000).

Lauderdale and Rathouz (2000) assessed 254,153 individuals from six different Asian American ethnic groups: Chinese, Filipino, Japanese, Asian Indian, Korean, and Vietnamese females and males ranging in age from 18-59 years. This cross-sectional study measured body weight, height, calculated BMI, age, sex, years lived in the United States, household income, and household size. Results revealed the percentage overweight ranged from $17 \%$ for Vietnamese males compared to $42 \%$ for Japanese males. For women, the percentage overweight ranged from $9 \%$ for Chinese and Vietnamese and $25 \%$ for Asian Indians. According to Oza-Frank et al. (2009), regardless of BMI classification, Asian Indians and Filipinos had higher prevalence rates of overweight (34-37\% and $35-47 \%$, respectively) compared to Chinese (30-38\%).

\section{Differences in End Point Disease Develop- ment}

T2 DM is one of the disease conditions associated with obesity and the development of metabolic syndrome. There are disproportionate differences in diabetes rates between the various ethnic groups. McNeely and Boyko (2004) demonstrated Asians have lower BMI values but tend to have a disproportionate disparity in cardiovascular mortality due to comorbidities such as uncontrolled blood sugar levels, elevated lipid levels, and high blood pressure. According to Karter et al. (2013), high rates of diabetes in
Asian Americans (Japanese, Chinese, Korean, Vietnamese, and Filipinos) can lead to co-morbid cardiovascular complications - assessed 210,632 participants from the Northern California Kaiser Permanente diabetes study. Pacific Islanders, South Asians, and Filipinos had the highest rates of diabetes, but findings were obscured by lower rates of participants among the larger Asian groups (i.e., Chinese) and several smaller Asian American subgroups. Jih et al. (2014) found overweight and obesity was highest among Filipinos. They concluded Filipinos should be the priority for overweight and obesity prevention as Filipinos and other Asian American subgroups in their study had higher prevalence rates for diabetes.

Studies of Southeast Asians living in the United States were found to have significantly higher prevalence of T2 DM (Araneta \& Barrett-Connor, $2005)$ with rates as high as $23 \%$ compared to Whites (6\%), African Americans (18\%), and Latinos (17\%; Araneta \& Barrett-Connor, 2005). According to results from the SEARCH for Diabetes in Youth Study Group (Hamman et al., 2014) it is becoming more and more difficult to differentiate between type 1 and T2 DM in those younger than 35 years of age in East Asia because BMI (approximately $24 \mathrm{~kg} / \mathrm{m}^{2}$ ) is equally low for both types of disease. This is not the case in other ethnic groups where the average BMI associated with $\mathrm{T} 2 \mathrm{DM}$ is around $27 \mathrm{~kg} / \mathrm{m}^{2}$.

While not part of this review, international studies have supported the findings of Asians living in the United States. For example, international studies comparing T2 DM between white Europeans and South Asian (i.e., Chinese, Japanese) subgroups found South Asians were more likely to develop T2 DM (Deurenberg-Yap, 2000; Ko et al., 1999; Sohani et al., 2014; Yajnik, 2002).

Ethnic/racial subgroups that may have a higher incidence of co-morbid diseases such as diabetes and CVD are Native Hawaiians and other Pacific Islanders due to their propensity for obesity. The association of high BMI values and a greater percentage of body fat associated with T2 DM and heart disease is a logical progression of disease trajectory for Native Hawaiians and other Pacific Islanders. This is not so in the Asian American population as the current research is beginning to uncover the BMI paradox associated with similar diseases in Asians. East Asians (Koreans, Chinese, and Japanese) are more likely to have smaller BMIs or waist circumferences but have a higher associated risk for developing T2 DM. The Japanese American Community Diabetes Study helped explain this paradox. This prospective study of 2 nd and $3 \mathrm{rd}$ generation Japanese Americans found visceral fat measured by computed tomography was the overarching risk factor for the development of T2 DM, hypertension, coronary heart disease, insulin resistance, and 
Table 2. Summary of Research Studies Included in the Review

\begin{tabular}{|c|c|c|c|c|c|c|}
\hline Authors & $\begin{array}{c}\text { Study Design \& } \\
\text { \# of Participants }\end{array}$ & Age & Ethnic Groups & Aim & Measures & Outcomes \\
\hline $\begin{array}{l}\text { Albrecht et al. } \\
\text { (2013) }\end{array}$ & $\begin{array}{l}\text { Secondary data } \\
\text { analysis of longi- } \\
\text { tudinal study } \\
N=2,288\end{array}$ & $45-84$ & $\begin{array}{l}\text { - Hispanic } \\
\text { - Chinese }\end{array}$ & $\begin{array}{l}\text { Examine whether foreign- } \\
\text { born participants experi- } \\
\text { enced greater increases in } \\
\text { BMI and waist circumfer- } \\
\text { ence than US-born over a } \\
\text { median follow-up of five } \\
\text { years }\end{array}$ & $\begin{array}{l}\text { - Weight } \\
\text { - Height } \\
\text { - } \text { BMI } \\
\text { - Waist circumfer- } \\
\text { ence }\end{array}$ & $\begin{array}{l}\text { - Foreign-born Hispanics and Chinese had lower } \\
\text { adjusted mean BMI and waist circumference at } \\
\text { base-line compared to US-born Hispanics and } \\
\text { Chinese } \\
\text { - Mexican Hispanics had greater waist circum- } \\
\text { ference over time compared to US-born Mexi- } \\
\text { can Hispanics } \\
\text { - Foreign-born Mexican Hispanics had a faster } \\
\text { rate of waist circumference increase compared } \\
\text { to foreign-born non-Mexican Hispanics }\end{array}$ \\
\hline $\begin{array}{l}\text { Araneta \& } \\
\text { Barrett-Con- } \\
\text { nor }(2005)\end{array}$ & $\begin{array}{l}\text { Descriptive sec- } \\
\text { ondary data anal- } \\
\text { ysis } \\
N=570\end{array}$ & $55-80$ & $\begin{array}{l}\text { - } \text { Filipino females } \\
\text { - African Ameri- } \\
\text { cans females } \\
\text { - Caucasian fe- } \\
\text { males }\end{array}$ & $\begin{array}{l}\text { Examine ethnic differences } \\
\text { in visceral adipose tissue as- } \\
\text { sessed by computed tomog- } \\
\text { raphy and type } 2 \text { diabetes } \\
\text { risk in women without car- } \\
\text { diovascular disease }\end{array}$ & $\begin{array}{l}\text { - Weight } \\
\text { - Height } \\
\text { - } \text { BMI } \\
\text { - Visceral adipose } \\
\text { tissue }\end{array}$ & $\begin{array}{l}\text { - Filipino women had lower BMI and waist girth } \\
\text { compared to African-American women } \\
\text { - Filipino women had significantly higher vis- } \\
\text { ceral adipose tissue compared to the other two } \\
\text { groups } \\
\text { - Visceral adipose tissue correlated with BMI and } \\
\text { waist circumference better for whites compared } \\
\text { to Filipinos } \\
\text { - Age-adjusted type } 2 \text { diabetes risk was higher } \\
\text { for Filipino women compared to the other } \\
\text { groups }\end{array}$ \\
\hline $\begin{array}{l}\text { Bates, } \\
\text { Acevedo-Gar- } \\
\text { cia, Alegría, } \\
\& \quad \text { Krieger } \\
(2008)\end{array}$ & $\begin{array}{l}\text { Descriptive } \\
\text { data from the Na- } \\
\text { tional Latino \& } \\
\text { Asian American } \\
\text { Survey (2002- } \\
2003) \\
N=4,649\end{array}$ & $\geq 18$ & $\begin{array}{l}\text { - } \text { Puerto Rican } \\
\text { - Cuban } \\
\text { - Mexican } \\
\text { - Other Latinos } \\
\text { - } \text { Chinese } \\
\text { - } \text { Vilipino } \\
\text { - Other Asian } \\
\text { Americans }\end{array}$ & $\begin{array}{l}\text { Examine BMI and obesity } \\
\text { among a representative sam- } \\
\text { ple of first, second, and third } \\
\text { generation Latinos and } \\
\text { Asian Americans to uncover } \\
\text { associations with nativity or } \\
\text { country of origin }\end{array}$ & $\begin{array}{l}\text { - Weight } \\
\text { - Height } \\
\text { - BMI }\end{array}$ & $\begin{array}{l}\text { - Great heterogeneity in BMI and obesity by } \\
\text { country of origin } \\
\text { - BMI increase in later generations among most } \\
\text { subgroups } \\
\text { - Different patterning for Latinos and Asian } \\
\text { Americans in nature \& distribution changes in } \\
\text { BMI with generational status in the US }\end{array}$ \\
\hline $\begin{array}{l}\text { Fujimoto et al. } \\
\text { (2012) }\end{array}$ & $\begin{array}{l}\text { Cross-sectional } \\
N=658\end{array}$ & $\geq 18$ & $\begin{array}{l}\text { - Several genera- } \\
\text { tions of Japanese } \\
\text { Americans }\end{array}$ & $\begin{array}{l}\text { Learn more about the etiol- } \\
\text { ogy and pathogenesis of } \\
\text { type } 2 \text { diabetes in Japanese } \\
\text { Americans }\end{array}$ & $\begin{array}{l}\text { - Weight } \\
\text { - Height } \\
\text { - BMI } \\
\text { - Visceral adiposity } \\
\text { - Type } 2 \text { diabetes }\end{array}$ & $\begin{array}{l}\text { - Japanese Americans had a greater risk for type } \\
2 \text { diabetes with increased weight gain, espe- } \\
\text { cially visceral adiposity }\end{array}$ \\
\hline
\end{tabular}




\begin{tabular}{|c|c|c|c|c|c|c|}
\hline Authors & $\begin{array}{c}\text { Study Design \& } \\
\text { \# of Participants }\end{array}$ & Age & Ethnic Groups & Aim & Measures & Outcomes \\
\hline $\begin{array}{l}\text { Gallagher et } \\
\text { al. (2000) }\end{array}$ & $\begin{array}{l}\text { Cross-sectional } \\
N=1,626\end{array}$ & $20-79$ & $\begin{array}{l}\text { - Whites } \\
\text { - } \text { Blacks } \\
\text { - Japanese }\end{array}$ & $\begin{array}{l}\text { Examine an approach for } \\
\text { developing percentage of } \\
\text { body fat ranges }\end{array}$ & $\begin{array}{l}\text { - } \text { BMI } \\
\text { - DXA } \\
\text { - Tritium or deuter- } \\
\text { ium dilution vol- } \\
\text { ume } \\
\text { - Bone mineral } \\
\text { mass }\end{array}$ & $\begin{array}{l}\text { - African-American women had the highest } \\
\text { mean weight } \\
\text { - Japanese men and women had the lowest mean } \\
\text { weight } \\
\text { - Japanese had the highest percentage body fat } \\
\text { for any given BMI } \\
\text { - Predictive models for Japanese indicated differ- } \\
\text { ent percentage body fat from that predicted for } \\
\text { African Americans and Whites }\end{array}$ \\
\hline $\begin{array}{l}\text { Gomez, Kel- } \\
\text { sey, Glaser, } \\
\text { Lee, \& Sidney } \\
(2004)\end{array}$ & $\begin{array}{l}\text { Case-controlled } \\
\text { study } \\
N=5,581(3,168 \\
\text { participants, } \\
2,413 \text { controls })\end{array}$ & $\geq 45$ & $\begin{array}{ll}\text { - } & \text { Chinese } \\
\text { - } & \text { Japanese } \\
\text { - } & \text { Mulipinos } \\
& \text { Asian }\end{array}$ & $\begin{array}{l}\text { Determine how risk factors } \\
\text { for disease vary among } \\
\text { Asian subgroups }\end{array}$ & $\begin{array}{l}\text { - Weight } \\
\text { - Height } \\
\text { - BMI } \\
\text { - Smoking history } \\
\text { - Dietary factors } \\
\text { o soy milk } \\
\text { o tofu } \\
\text { o alcohol } \\
\text { - Physical activity } \\
\text { - Overall health } \\
\text { - History of chronic } \\
\text { disease }\end{array}$ & $\begin{array}{l}\text { - Japanese and Chinese had lower BMI than } \\
\text { other Asian subgroups } \\
\text { - Subgroups born in the US were associated with } \\
\text { having BMIs }>25 \\
\text { - Japanese and multiple race Asians were more } \\
\text { likely to smoke } \\
\text { - Filipinos and multiple race Asians were more } \\
\text { likely to start smoking at age } 18 \text { or younger } \\
\text { - Filipinos and multiple race Asians were more } \\
\text { likely to report diabetes }\end{array}$ \\
\hline $\begin{array}{l}\text { Huang et al. } \\
\text { (1996) }\end{array}$ & $\begin{array}{l}\text { Cross-sectional } \\
N=8,006\end{array}$ & $>18$ & $\begin{array}{l}\text { - Japanese males in } \\
\text { the US }\end{array}$ & $\begin{array}{l}\text { Determine the association } \\
\text { between acculturation and } \\
\text { prevalence of diabetes }\end{array}$ & $\begin{array}{l}\text { - BMI } \\
\text { - Physical activity } \\
\text { index } \\
\text { - Oxygen consump- } \\
\text { tion } \\
\text { - percentage of cal- } \\
\text { ories for carbohy- } \\
\text { drates and fats }\end{array}$ & $\begin{array}{l}\text { - Number of years lived in Japan was inversely } \\
\text { associated with the development of diabetes } \\
\text { - Japanese diet (from native country) was in- } \\
\text { versely associated with diabetes }\end{array}$ \\
\hline $\begin{array}{l}\text { Jih et al. } \\
(2014)\end{array}$ & $\begin{array}{l}\text { Secondary data } \\
\text { analysis of the } \\
2009 \text { adult Cali- } \\
\text { fornia Health In- } \\
\text { terview Survey } \\
N=45,946\end{array}$ & $\geq 18$ & $\begin{array}{l}\text { - } \text { non-Hispanic } \\
\text { - African Ameri- } \\
\text { cans } \\
\text { - Hispanics } \\
\text { - Vietnamese } \\
\text { - Chinese } \\
\text { - Korean } \\
\text { - Filipino } \\
\text { - South Asian }\end{array}$ & $\begin{array}{l}\text { Examine the prevalence of } \\
\text { overweight/obesity using } \\
\text { BMI cut points recom- } \\
\text { mended by WHO for Asian } \\
\text { Americans }\end{array}$ & $\begin{array}{l}\text { - Weight } \\
\text { - Height } \\
\text { - BMI }\end{array}$ & $\begin{array}{l}\text { - Highest rates of overweight/obesity were } \\
\text { among Filipinos }(78.6 \%) \text { higher than non-His- } \\
\text { panic Whites and similar to African Americans } \\
\text { and Hispanics } \\
\text { - Diabetes prevalence was higher among Viet- } \\
\text { namese, Koreans, Filipinos, and South Asians } \\
\text { with BMIs } 23.0-24.9 \mathrm{~kg} / \mathrm{m} 2 \\
\text { - Using WHO BMI cut points of } 27.5-28.9 \\
\mathrm{~kg} / \mathrm{m}^{2}, \text { Koreans, Filipinos, and Japanese had the } \\
\text { highest prevalence of diabetes }\end{array}$ \\
\hline
\end{tabular}




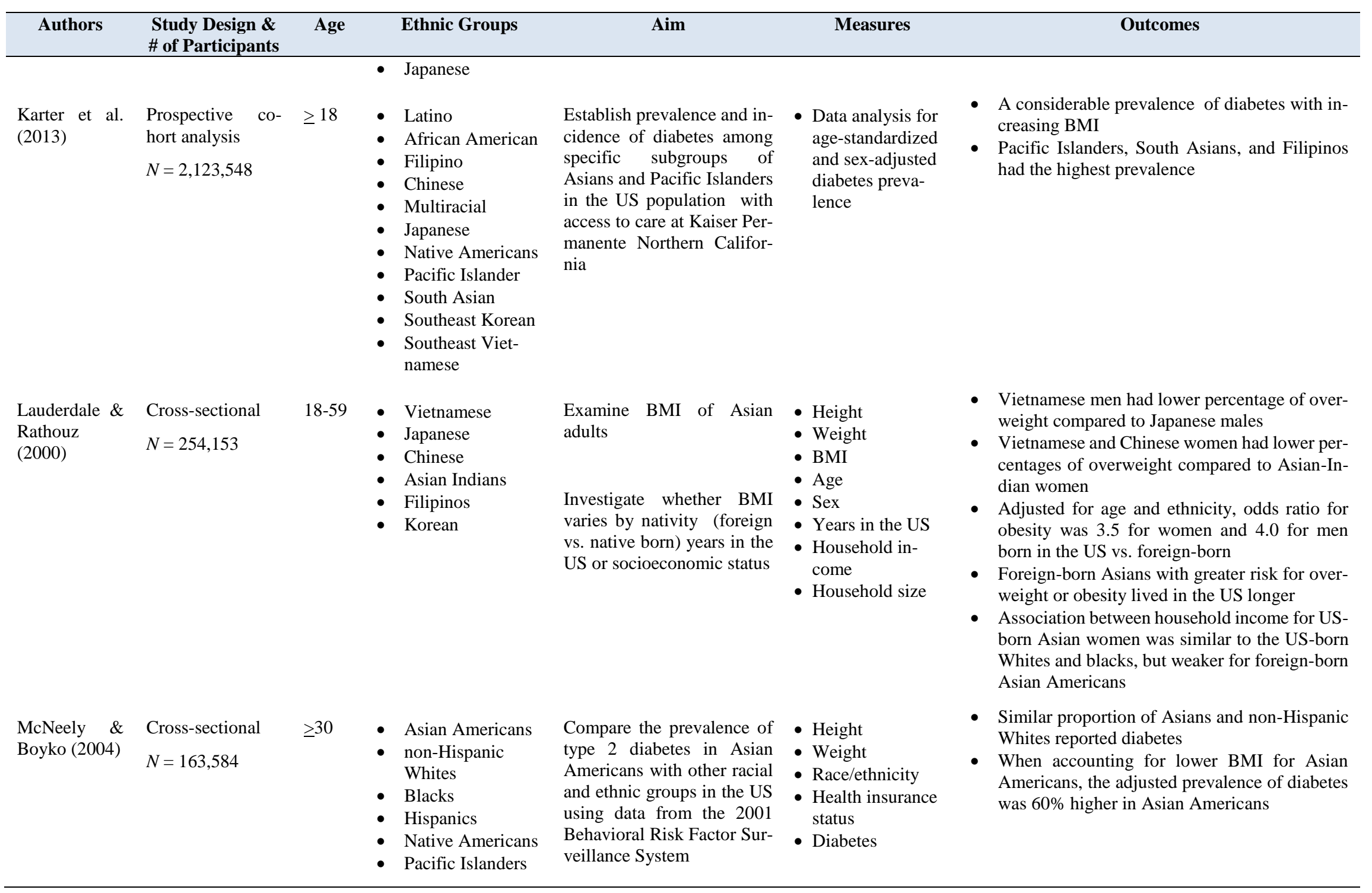




\begin{tabular}{|c|c|c|c|c|c|c|}
\hline Authors & $\begin{array}{c}\text { Study Design \& } \\
\text { \# of Participants }\end{array}$ & Age & Ethnic Groups & Aim & Measures & Outcomes \\
\hline $\begin{array}{l}\text { Ogden, Car- } \\
\text { roll, Kit, \& } \\
\text { Flegal }(2014)\end{array}$ & $\begin{array}{l}\text { Cross-sectional } \\
N=5,181 \text { adults }\end{array}$ & $\geq 20$ & $\begin{array}{ll}\text { - } & \text { non-Hispanic } \\
& \text { Blacks } \\
\text { - } & \text { non-Hispanic } \\
\text { - } & \text { Hsians } \\
\text { - } & \text { nispanics } \\
& \text { Whites }\end{array}$ & $\begin{array}{l}\text { Provide detailed obesity } \\
\text { trend analyses by age } \\
\text { among adults }\end{array}$ & $\begin{array}{l}\text { - BMI } \\
\text { - Weight } \\
\text { - Height }\end{array}$ & $\begin{array}{l}\text { - } 2 / 3 \text { of adults were either overweight or obese } \\
\text { - Prevalence was higher among women } \\
\text { - Prevalence highest among the middle-aged } \\
\text { group and adults aged } 60 \text { years and older } \\
\text { - Grade } 3 \text { obesity prevalence highest for non-His- } \\
\text { panic blacks } \\
\text { - } 10.9 \% \text { of non-Hispanic Asian adults were obese } \\
\text { - No considerable change in obesity prevalence } \\
\text { in adults between } 2003-2004 \text { and 2011-2012. }\end{array}$ \\
\hline $\begin{array}{l}\text { Oakkar et al. } \\
(2015)\end{array}$ & $\begin{array}{l}\text { Prospective longi- } \\
\text { tudinal } \\
N=1,549\end{array}$ & $44-71$ & $\begin{array}{ll}\text { - } & \text { Chinese } \\
\text { - Japanese } \\
\text { - Vietnamese } \\
\text { - Korean }\end{array}$ & $\begin{array}{l}\text { Determine differences in } \\
\text { changes in BMI across age } \\
\text { by residence (US vs. Asia) } \\
\text { and age at immigration us- } \\
\text { ing longitudinal data on } \\
\text { BMI prior to and after immi- } \\
\text { gration }\end{array}$ & $\begin{array}{l}\text { - BMI at ages } \\
30,40,50 \text {, and } 60 \\
\text { years of age } \\
\text { - Self-report weight } \\
\text { and current height }\end{array}$ & $\begin{array}{l}\text { BMI increases were smaller for Asians who } \\
\text { lived in Asia prior to migrating to the US com- } \\
\text { pared to those already living here } \\
\text { - Those who migrated to the US prior to } 40 \text { years } \\
\text { of age had higher BMI compared to those who } \\
\text { migrated at a later age }\end{array}$ \\
\hline $\begin{array}{l}\text { Oza-Frank, } \\
\text { Ali, Vacca- } \\
\text { rino, \& Nara- } \\
\text { yan (2009) }\end{array}$ & $\begin{array}{l}\text { Descriptive } \\
\text { Data on Asian } \\
\text { American adults } \\
N=147,705\end{array}$ & $18-74$ & $\begin{array}{l}\text { - Asian Indians } \\
\text { - Chinese } \\
\text { - Filipinos } \\
\text { - Non-Hispanic } \\
\text { Whites }\end{array}$ & $\begin{array}{l}\text { Compare the prevalence of } \\
\text { diabetes among Asian } \\
\text { Americans by the WHO and } \\
\text { US BMI classifications }\end{array}$ & $\begin{array}{l}\text { - Height } \\
\text { - Weight } \\
\text { - BMI }\end{array}$ & $\begin{array}{l}\text { Regardless of classification, Asian Indians and } \\
\text { Filipinos had higher prevalence of obesity com- } \\
\text { pared to Chinese } \\
\text { - Asian Indians also had higher ethnic prevalence } \\
\text { for diabetes than the other Asian Americans }\end{array}$ \\
\hline $\begin{array}{l}\text { Oza-Frank \& } \\
\text { Narayan } \\
(2010)\end{array}$ & $\begin{array}{l}\text { Cross-sectional } \\
\text { data from Na- } \\
\text { tional Health In- } \\
\text { terview Survey } \\
(1997-2005) \\
N=7,414\end{array}$ & $18-74$ & $\begin{array}{l}\text { Individuals migrating } \\
\text { from the following } \\
\text { countries to live in } \\
\text { the US: } \\
\text { - Mexico } \\
\text { - South America } \\
\text { - Europe } \\
\text { - Russia } \\
\text { - Africa } \\
\text { - Middle } \\
\text { - Indian subconti- } \\
\text { - } \text { nent } \\
\text { Southeast Asia }\end{array}$ & $\begin{array}{l}\text { Establish an association be- } \\
\text { tween length of residence in } \\
\text { US and overweight among } \\
\text { immigrants by region of } \\
\text { birth and age at arrival }\end{array}$ & - Self-report survey & $\begin{array}{l}\text { - Overweight odds three times higher in immi- } \\
\text { grants from Mexico, South America, Europe, } \\
\text { Russia, Africa, and Middle East for those resid- } \\
\text { ing in the US for greater than } 15 \text { years } \\
\text { - Those who migrated from Indian subcontinent } \\
\text { and South East Asians had no association with } \\
\text { length of stay in the US and overweight } \\
\text { - South East Asians and Africans had lower odds } \\
\text { of being overweight } \\
\text { - For African and Southeast Asian women aged } \\
24-44 \text { years of age, the odds of being over- } \\
\text { weight were greater than other ethnic/racial } \\
\text { groups }\end{array}$ \\
\hline
\end{tabular}




\begin{tabular}{|c|c|c|c|c|c|c|}
\hline Authors & $\begin{array}{c}\text { Study Design \& } \\
\text { \# of Participants }\end{array}$ & Age & Ethnic Groups & Aim & Measures & Outcomes \\
\hline $\begin{array}{l}\text { Park, Necker- } \\
\text { man, Quinn, } \\
\text { Weiss, \& } \\
\text { Rundle }(2008)\end{array}$ & $\begin{array}{l}\text { Cross-sectional } \\
N=13,011\end{array}$ & $\geq 18$ & $\begin{array}{ll}\text { - } & \text { Asians } \\
\text { - } & \text { Black-Caribbean } \\
\text { - Hispanic }\end{array}$ & $\begin{array}{l}\text { Examine the theory that im- } \\
\text { migrant groups length of } \\
\text { residence in the US and } \\
\text { across generations results in } \\
\text { weight gain }\end{array}$ & $\begin{array}{l}\text { - Weight } \\
\text { - Height } \\
\text { - BMI } \\
\text { - Diet } \\
\text { - Physical activity }\end{array}$ & $\begin{array}{l}\text { - Foreign-born associated with significantly } \\
\text { lower BMI but this association was weakest in } \\
\text { Asians } \\
\text { - Among Hispanics, association between foreign } \\
\text { birth and BMI was stronger in low linguistic } \\
\text { isolation neighborhoods } \\
\text { - Increased residence in the US was significantly } \\
\text { associated with higher BMI }\end{array}$ \\
\hline $\begin{array}{l}\text { Palaniappan, } \\
\text { Wong, Shin, } \\
\text { Fortmann, \& } \\
\text { Lauderdale } \\
\text { (2011) }\end{array}$ & $\begin{array}{l}\text { Descriptive retro- } \\
\text { spective (self-re- } \\
\text { port) data analysis } \\
\text { using electronic } \\
\text { medical records } \\
\text { from a health care } \\
\text { organization in } \\
\text { San Francisco } \\
N=47,507\end{array}$ & $\geq 35$ & $\begin{array}{l}\text { - } \text { Chinese } \\
\text { - } \text { Filipino } \\
\text { - Jsian Indian } \\
\text { - Kapanese } \\
\text { - } \text { Kietrean } \\
\text { - non-Hispanic } \\
\quad \text { White }\end{array}$ & $\begin{array}{l}\text { Examine the relationship } \\
\text { between BMI and metabolic } \\
\text { syndrome for Asian Ameri- } \\
\text { cans and non-Hispanic } \\
\text { Whites given the ethnic/ra- } \\
\text { cial heterogeneity of the } \\
\text { ability to predict metabolic } \\
\text { syndrome using BMI }\end{array}$ & $\begin{array}{l}\text { - Height } \\
\text { - Weight } \\
\text { - BMI } \\
\text { - Metabolic syn- } \\
\text { drome }\end{array}$ & $\begin{array}{l}\text { - Overall metabolic syndrome rates were higher } \\
\text { for Asians compared to non-Hispanic Whites } \\
\text { - BMI of } 25 \mathrm{~kg} / \mathrm{m}^{2} \text { at age } 55 \text {, the predicted rate of } \\
\text { metabolic syndrome for Non-Hispanic White } \\
\text { women was } 12 \% \text { compared to } 30 \% \text { for Asian } \\
\text { females }\end{array}$ \\
\hline $\begin{array}{l}\text { Sánchez- } \\
\text { Vaznaugh, } \\
\text { Kawachi, } \\
\text { Subramanian, } \\
\text { Sánchez, \& } \\
\text { Acevedo-Gar- } \\
\text { cia (2008) }\end{array}$ & $\begin{array}{l}\text { Cross-sectional } \\
\text { population data } \\
\text { from the } 2001 \\
\text { California Health } \\
\text { Interview Survey } \\
N=37,350\end{array}$ & $25-64$ & $\begin{array}{ll}\text { - } & \text { Whites } \\
\text { - } & \text { Blacks } \\
\text { - } & \text { Hispanics } \\
\text { - } & \text { Chinese } \\
\text { - } & \text { Kietnamese } \\
\text { - } & \text { Cambodian } \\
\text { - Pacific Islander } \\
\text { - Other Asian } \\
\text { - } \text { Asian with } 2 \text { or } \\
& \text { more ethnicities }\end{array}$ & $\begin{array}{l}\text { Investigate whether the in- } \\
\text { fluence of birthplace-length } \\
\text { of residence on BMI varied } \\
\text { by education, gender, and } \\
\text { race/ethnicity }\end{array}$ & $\begin{array}{l}\text { - Weight } \\
\text { - Height } \\
\text { - BMI }\end{array}$ & $\begin{array}{l}\text { - Foreign-born adults had lower BMI than US- } \\
\text { born adults } \\
\text { - Longer residence in the US was associated with } \\
\text { higher BMI } \\
\text { - The effect of birthplace-length of US residence } \\
\text { on BMI difference by education, gender, and } \\
\text { race/ethnicity }\end{array}$ \\
\hline
\end{tabular}

Note. US = United States 
metabolic syndrome (Fujimoto et al., 2012). It is becoming apparent that diagnosing metabolic syndrome in Asian individuals using the same criteria for other ethnic groups is inappropriate (see Table 2).

\section{Discussion}

Given the currently available data on Asian immigrants/Asian Americans, it is now evident that lower BMIs need to be used to distinguish normal weight individuals from those that are overweight or obese. It is also becoming increasingly evident that despite lower BMIs, Asian immigrants/Asian Americans have greater percentages of body fat compared to their Caucasian counterparts given similar age, sex, and BMI. Given these known factors, there are still many questions left unanswered as evident from the results of this review.

There are several areas identified in the literature that differentiates Asian immigrants/Asian Americans and other ethnic/racial groups for BMI measurements and body fat percentages. It is evident from this analysis that there are differences in measurements between Asian immigrant/Asian American subgroups. Because the data from the various studies have produced mixed results, it is clear a concerted effort is needed to collect data that builds on the current knowledge to strengthen this body of research. One way to help produce the necessary data is by oversampling Asian immigrant/Asian American subgroups. By doing so, a better understanding of the relationship of body fat for the various Asian subgroups and the risk for CVD and diabetes may emerge. Another important area identified from this literature review is the need to use the modified BMI cut point for Asian immigrants/Asian Americans for greater accuracy in identifying risk for disease. The BMI cut points used in longitudinal prospective studies have verified that recommended BMI modifications are accurate for the Asian immigrant/Asian American populations.

The focus of future research studies needs to use a more global perspective comparing subgroups of Asians in their native countries to those who migrate to the United States. Conducting longitudinal comparison studies looking particularly at acculturation and generational changes in BMI and disease risk or disease patterns can help to generate data on health disparities among the Asian immigrant/Asian American subgroups; an important first step to devising more effective disease prevention strategies for this population. Greater attention should be paid to the socioeconomic status of immigrant Asians and assimilation patterns to determine the associations of life style behaviors with the development of weight gain, specifically body fat distribution and BMI. Additionally, studies need to be designed to consistently include the various subgroups of Asian immigrants/Asian Americans to discern the differences in body fat distribution and risk for developing CVD and T2 DM. Many of the studies in this review included Asian immigrant/Asian American subgroupings as an aggregate group, this is not the most desirable research design. With approximately 23 different Asian subgroups; some with smaller numbers in the United States (i.e., Hmong, Thailanders, Cambodians, etc.), potential study participants' ethnic/racial subgroups should be identified to yield more valuable information. There is some support for differences in $\mathrm{BMI} /$ body fat percentage in some of the Asian immigrant/Asian American subgroups rendering them more susceptible for CVD. What is not clear is the degree to which genetics influences this relationship. Genetics may play a more important role in the development of metabolic syndrome in some Asian immigrant/Asian American subgroups; particularly a genetic predisposition of vulnerability with exposure to the Western lifestyle.

\section{Conclusion}

This review indicates Asian immigrants or Asian Americans have an increased risk for diabetes and CVD with lower BMI cut points. At lower BMI parameters, Asian Americans have greater percentages of body fat which garners the risk for metabolic syndrome. While it is important to continue research, this finding also has clinical implications. Traditionally, research evidence takes approximately 17 years to become a standard guideline in practice. Initiating treatment based on this modified BMI cut point, now rather than waiting, may help prevent or contribute to improved health care and overall quality of life for Asians.

\section{References}

Albrecht, S. S., Diez Roux, A. V., Kandula, N. R., Osypuk, T. L., Ni, H., \& Shrager, S. (2013). Immigrant assimilation and BMI and waist size: A longitudinal examination among Hispanic and Chinese participants in the multi-ethnic study of atherosclerosis. Obesity, 21, 1695-1703. doi:10.1002/oby.20104

Araneta, M. R., \& Barrett-Connor, E. (2005). Ethnic differences in visceral adipose tissue and type 2 diabetes: Filipino, African-American, and white women. Obesity Research, 13, 1458-1465. doi:10.1038/oby.2005.176

Bates, L. M., Acevedo-Garcia, D., Alegría, M., \& Krieger, N. (2008). Immigration and generational trends in body mass index and obesity in the United States: Results of the National Latino and Asian American Survey, 2002-2003. Journal American Public Health Association, 98, 70-77. doi:10.2105/AJPH.2006.102814 


\section{Alpert and Thomason: Differences for Asian Americans in Percentage of Body Fat}

Centers for Disease Control and Prevention [CDC]. (2015). About adult BMI: How is BMI interpreted for adults? Retrieved from http://www.cdc.gov/healthyweight/assessing/bmi/adult_bmi/index.html

Colby, S. L., \& Ortman, J. M. (2014). Projections of the size and composition of the U.S. population: 2014 to 2060 (Current Population Reports, P25-1143, U.S. Census Bureau). Retrieved from https://www.census.gov/content/dam/Census/library/publications/2015/demo/p25-1143.pdf

Després, J. P. (2012). Body fat distribution and risk of cardiovascular disease: An update. Circulation, 126, 1301-1313. doi:10.1161/CIRCULATIONAHA.111.067264

Després, J. P., Couillard, C., Gagnon, J., Bergeron, J., Leon, A. S., Rao, D. C., . . Bouchard, C. (2000). Race, visceral adipose tissue, plasma lipids, and lipoprotein lipase activity in men and women: The Health, Risk Factors, Exercise Training, and Genetics (HERITAGE) family study. Thrombosis and Vascular Biology, 20, 1932-1938. doi:10.1161/01.ATV.20.8.1932

Deurenberg-Yap, M., Chew, S. K., Lin, V. F., Tan, B. Y., van Staveren, W. A., \& Deurenberg, P. (2001). Relationships between indices of obesity and its co-morbidities in multi-ethnic Singapore. International Journal of Obesity and Related Metabolic Disorders, $\quad 25, \quad 1554-1562$. doi:10.1038/sj.ijo.0801739

Deurenberg-Yap, M., Schmidt, G., van Staveren, W. A., \& Deurenberg, P. (2000). The paradox of low body mass index and high body fat percentage among Chinese, Malays and Indians in Singapore. International Journal of Obesity and Related Metabolic Disorders, 24, 1011-1017. doi:10.1038/sj.ijo.0801353

Ford, E. S., Giles, W. H., \& Dietz, W. H. (2002). Prevalence of the metabolic syndrome among US adults: Findings from the third National Health and $\mathrm{Nu}-$ trition Examination Survey. Journal of the American Medical Association, 287, 356-359. doi:10.1001/jama.287.3.356

Fujimoto, W. Y., Bergstrom, R. W., Boyko, E. J., Chen, K. W., Leonetti, D. L., Newell-Morris, L., . . W Wahl, P. W. (1999). Visceral adiposity and incident coronary heart disease in Japanese-American men. The 10-year follow-up results of the Seattle Japanese-American Community Diabetes Study. Diabetes Care, 22, 1808-1812. doi:10.2337/diacare.22.11.1808

Fujimoto, W. Y., Boyko, E. J., Hayashi, T., Kahn, S. E., Leonetti, D. L., McNeely, M. J., \& Shuman, W. P. (2012). Risk factors for type 2 diabetes: Lessons learned from Japanese Americans in Seattle. Journal of Diabetes Investigation, 3, 212-224. doi:10.1111/j.2040-1124.2012.00195.x

Gallagher, D., Heymsfield, S. B., Heo, M., Jebb, S. A., Murgatroyd, P. R., \& Sakamoto, Y. (2000). Healthy percentage body fat ranges: An approach for developing guidelines based on body mass index. American Journal of Clinical Nutrition, 72, 694701.
Gomez, S. L., Kelsey, J. L., Glaser, S. L., Lee, M. M., \& Sidney, S. (2004). Immigration and acculturation in relation to health and health-related risk factors among specific Asian subgroups in a health maintenance organization. American Journal of Public Health, 94, 1977-1984. doi:10.2105/AJPH.94.11.1977

Hamman RF, Bell RA, Dabelea D, D'Agostino RB, Dolan L, Imperatore G........Saydah S. for the SEARCH for Diabetes in Youth Study Group. (2014). The SEARCH for Diabetes in Youth Study: Rationale, findings, and future directions. Diabetes Care, 37, 3336-3344.

Han, T. S., Williams, K., Sattar, N., Hunt, K. J., Lean, M. E., \& Haffner, S. M. (2002). Analysis of obesity and hyperinsulinemia in the development of metabolic syndrome: San Antonio Heart Study. Obesity Research, 10, 923-931. doi:10.1038/oby.2002.126

Huang, B., Rodriguez, B. L., Burchfiel, C. M., Chyou, P. H., Curb, J. D., \& Yano, K. (1996). Acculturation and prevalence of diabetes among Japanese-American men in Hawaii. American Journal of Epidemiology, 144, 674-681. doi:10.1093/oxfordjournals.aje.a008980

Hsu, W. C., Araneta, M. R., Kanaya, A. M., Chiang, J. L., Fujimoto, W., \& Fujimoto, W. (2015). BMI cut points to identify at-risk Asian Americans for type 2 diabetes screening. Diabetes Care, 38, 150-158. doi:10.2337/dc14-2391

Jee, S. H., Sull, J. W., Park, J., Lee, S. Y., Ohrr, H., Guallar, E., \& Samet, J. M. (2006). Body-mass index and mortality in Korean men and women. New England Journal of Medicine, 355, 779-787. doi:10.1056/NEJMoa054017

Jih, J., Mukherjea, A., Vittinghoff, E., Nguyen, T. T., Tsoh, J. Y., Fukuoka, Y., . ..........Kanaya A.M. (2014). Using appropriate body mass index cut points for overweight and obesity among Asian Americans. Preventive Medicine. doi:10.1016/j.ypmed.2014.04.010

Karter, A. J., Schillinger, D., Adams, A. S., Moffet, H. H., Liu, J., Adler, N. E., \& Kanaya, A. M. (2013). Elevated rates of diabetes in Pacific Islanders and Asian subgroups: The Diabetes Study of Northern California (DISTANCE). Diabetes Care, 36, 574579. doi:10.2337/dc12-0722

Kaushal, N. (2009). Adversities of acculturation? Prevalence of obesity among immigrants. Health Economics, 18, 291-303. doi:10.1002/hec. 1368

Ko, G. T., Chan, J. C., Cockram, C. S., \& Woo, J. (1999). Prediction of hypertension, diabetes, dyslipidaemia or albuminuria using simple anthropometric indexes in Hong Kong Chinese. International Journal of Obesity and Related Metabolic Disorders, 23, 1136-1142. doi:10.1038/sj.ijo.0801043

Lauderdale, D. S., \& Rathouz, P. J. (2000). Body mass index in a US national sample of Asian Americans: Effects of nativity, years since immigration and socioeconomic status. International Journal of Obesity and Related Metabolic Disorders, 24, 11881194. doi:10.1038/sj.ijo.0801365 
McNeely, M. J., \& Boyko, E. J. (2004). Type 2 diabetes prevalence in Asian Americans: Results of a national health survey. Diabetes Care, 27, 66-69. doi:10.2337/diacare.27.1.66

National Cholesterol Education Program (NCEP) Expert Panel on Detection, Evaluation, and Treatment of High Blood Cholesterol in Adults (Adult Treatment Panel III). (2002). Third report of the National Cholesterol Education Program (NCEP) expert panel on detection, evaluation, and treatment of high blood cholesterol in adults (Adult Treatment Panel III) final report. Circulation, 106, 3143-3421.

Oakkar, E. E., Stevens, J., Bradshaw, P. T., Cai, J., Ferreira, K. M., Popkin, B. M., . . .. ...Quinn, V.P. (2015). Longitudinal study of body mass index in Asian men who immigrate to the U.S. Asia Pacific Journal of Clinical Nutrition. doi:10.6133/apjen.2015.24.4.10

Ogden, C. L., Carroll, M. D., Kit, B. K., \& Flegal, K. M. (2013). Prevalence of obesity among adults: United States 2011-2012. NCHS data brief. No 131. Retrieved from: http://www.census.gov/prod/cen2010/briefs/c2010br-11.pdf

Ogden, C. L., Carroll, M. D., Kit, B. K., \& Flegal, K. M. (2014). Prevalence of childhood and adult obesity in the United States, 2011-2012. Journal of the American Medical Association, 311, 806-814. doi:10.1001/jama.2014.732

Oza-Frank, R., Ali, M. K., Vaccarino, V., \& Narayan, K. M. (2009). Asian Americans: Diabetes prevalence across U.S. and World Health Organization weight classifications. Diabetes Care, 32, 1644 1646. doi:10.2337/dc09-0573

Oza-Frank, R., \& Narayan, K. M. (2010). Effect of length of residence on overweight by region of birth and age at arrival among US immigrants. Public Health Nutrition, $\quad 13, \quad 868-875$. doi:10.1017/S1368980009992084

Palaniappan, L., Carnethon, M. R., Wang, Y., Hanley, A. J., Fortmann, S. P., Haffner, S. M., \& Wagenknecht, L. (2004). Predictors of the incident metabolic syndrome in adults: The Insulin Resistance Atherosclerosis Study. Diabetes Care, 27, 788-793.

Palaniappan, L. P., Wong, E. C., Shin, J. J., Fortmann, S. P., \& Lauderdale, D. S. (2011). Asian Americans have greater prevalence of metabolic syndrome despite lower body mass index. International Journal of Obesity, 35, 393-400. doi:10.1038/ijo.2010.152

Park, Y., Neckerman, K. M., Quinn, J., Weiss, C., \& Rundle, A. (2008). Place of birth, duration of residence, neighborhood immigrant composition and body mass index in New York City. International Journal of Behavioral Nutrition and Physical Activity, 5, 19. doi:10.1186/1479-5868-5-19

Sánchez-Vaznaugh, E. V., Kawachi, I., Subramanian, S. V., Sánchez, B. N., \& Acevedo-Garcia, D. (2008). Differential effect of birthplace and length of residence on body mass index (BMI) by education, gender and race/ethnicity. Social Science \& Medicine, 67, 1300-1310. doi:10.1016/j.socscimed.2008.06.015

Sohani, Z. N., Deng, W. Q., Pare, G., Meyre, D., Gerstein, H. C., \& Anand, S. S. (2014). Does genetic heterogeneity account for the divergent risk of type 2 diabetes in South Asian and white European populations? Diabetologia, 57, 2270-2281. doi:10.1007/s00125-014-3354-1

World Health Organization Expert Consultation. (2004). Appropriate body-mass index for Asian populations and its implications for policy and intervention strategies. Lancet, 363(9403), 157-163. doi:10.1016/s0140-6736(03)15268-3

Yajnik, C. S. (2002). The lifecycle effects of nutrition and body size on adult adiposity, diabetes and cardiovascular disease. Obesity Reviews, 3, 217-224. doi:10.1046/j.1467-789X.2002.00072.x

Yates, A., Edman, J., \& Aruguete, M. (2004). Ethnic differences in BMI and body/self-dissatisfaction among Whites, Asian subgroups, Pacific Islanders, and African-Americans. Journal of Adolescent Health, $34, \quad 300-307 . \quad$ doi:10.1016/S1054$139 \mathrm{X}(03) 00305-7$ 